УДК 581.9.6/.999.998

\title{
Two alien species of Asteraceae new to Uzbekistan (Bukhara oasis)
}

\author{
H. K. Esanov ${ }^{1}$, M. X. Usmonov ${ }^{2,3}$ \\ ${ }^{1}$ Bukhara State University, M. Ikbol str., 11, Bukhara, 200117,Uzbekistan.E-mail: husniddin1978@mail.ru \\ ${ }^{2}$ Central Herbarium, Institute of the Botany of Academy of Sciences of the Republic of Uzbekistan. \\ E-mail:mansur.usmonov@inbox.ru \\ ${ }^{3}$ Kongju National University, Department of Biology Education 309, 56 Gongjudaehak-ro, Gongju-si, \\ Chungcheongnam-do, 32582, Republic of Korea
}

Keywords: alien plants, distribution, Bukhara oasis, Erigeron, Symphyotrichum.

Summary. Asteraceae is one of the most diverse plant families in Central Asia, and in Uzbekistan in particular. In Uzbekistan, there are 598 species of Asteraceae which comprise $15 \%$ of the flora of the country. Seventy species of the family have been recorded from the Bukhara oasis in the south-western part of Uzbekistan, which makes it the greatest family by the number of species. Two alien species of Asteraceae were found as new to Uzbekistan. Erigeron bonariensis L., which has been presumably recently introduced, was observed with a limited number of populations, whereas Symphyotrichum graminifolium (Spreng.) G. L. Nesom is considered expanding invasive species. The present condition and distribution patterns of these species in the Bukhara oasis of Uzbekistan are described.

\section{Два чужеродных вида Asteraceae, новых для Узбекистана (Бухарский оазис)}

\author{
Х. К. Эсанов ${ }^{1}$, М. Х. Усмонов ${ }^{2,3}$ \\ ${ }^{1}$ Бухарский государственный университет, ул. М. Икбол, 11, Бухара, 200117, Узбекистан \\ ${ }^{2}$ Центральный гербарий, Институт ботаники Академии наук Республики Узбекистан, ул. Дурмон йули, 32, \\ 2. Ташкент, 100125, Узбекистан \\ ${ }^{3}$ Конжуйский национальный университет, факультет биологического образования 309, 56 Гонгюдаэхак-ро, \\ Гонджу-си, Чунчхоннам-до, 32582, Республика Корея
}

Ключевые слова: адвентивные виды растений, Бухарский оазис, распространение, Erigeron, Symphyotrichum.

Аннотация. Asteraceae является одним из самых многовидовых семейств растений в Средней Азии и, в том числе, в Узбекистане. В Узбекистане насчитывается 598 видов сем. Asteraceae, что составляет $15 \%$ от флоры страны. В Бухарском оазисе, расположенном в юго-западной части Узбекистана, зарегистрировано семьдесят видов сложноцветных, что делает данное семейство ведущим по числу представителей в регионе. Недавно здесь были впервые найдены два чужеродных вида астровых, оказавшихся новыми для Узбекистана. Erigeron bonariensis L., который, предположительно, был занесен недавно, наблюдался в ограниченном числе популяций, тогда как Symphyotrichum graminifolium (Spreng.) G. L. Nesom встречался гораздо чаще и в большем обилии. Описаны современное состояние и закономерности распространения этих видов в Бухарском оазисе Узбекистана. 
Asteraceae Dumort., one of the biggest families among flowering plants, includes 32913 species belonging to 1911 genera in the Earth (The Plant List, 2013). Asteraceae is one of the leading families in Central Asia, as well as in Uzbekistan. There are 598 species in Uzbekistan which comprise $15 \%$ of the flora of the country (Vvedensky, 1962). With seventy species observed in the Bukhara oasis, south-western Uzbekistan, Asteraceae is the leading family by the number of species (Esanov, Aslonova, 2015). This family is also remarkable in numerous alien species. During the field research made in 2007-2015, we discovered two further species of Asteraceae which had not been previously recorded in Uzbekistan or even the whole of Central Asia, i. e. in Erigeron L. and Symphyotrichum Nees.

There are more than 476 species of the genus Erigeron worldwide (The Plant List, 2013). In Central Asia 35 species have been recorded (Tulyaganova, 1993), and 25 of them have been known from Uzbekistan (Bondarenko, 1962). Until the present study only one species of the genus, Erigeron canadensis L., has been known from the whole territory of the Uzbekistan. During the field study carried out in 2014-2015, a second species, namely Erigeron bonariensis L. belonging to $E$. sect. Caenotus Nutt., was discovered.

The genus Symphyotrichum embraces ca. 90 species in the world with the North American native area (Chen, Brouillet, 2011). In the beginning and the middle of the $20^{\text {th }}$ century Symphyotrichum graminifolium was not known in Central Asia, and no species of this genus had been reported from Uzbekistan. However, two species of the genus (as Conyza graminifolia and C. squamata) were included in the "Conspectus florae Asiae Mediae" (Tulyaganova, 1993), and our study also proved that Symphyotrichum graminifolium is common in Uzbekistan. Symphyotrichum graminifolium is reported for the first time from Uzbekistan.

From the botanical-geographical perspective, Bukhara oasis is located in the Kyzylkum district in the lower part of the Zarafshan river and belongs to Turon province (Tojibaev et al., 2016). The area of the oasis is $2870 \mathrm{~km}^{2}$. Bukhara oasis is part of Bukhara region of the Republic of Uzbekistan. It is surrounded by sandy deserts. Natural climatic conditions are indicative of the arid climate, which corresponds to its geographical location. Its climate is dry and hot in summer and cold in winter. The amount of precipitation is very low, $90-150 \mathrm{~mm}$ per year on average (Nazarov, Allayorov, 1994). The study area includes natural and artificial landscapes which have been formed due to the conversion of desert areas into croplands.

Bukhara city is situated in the center of Bukhara oasis. This city is included into the famous cities of the world with its ancient monuments of Uzbekistan. More than 10000 tourists visit this city around the year, which is included in the List of World Heritage Sites of UNESCO. They are considered as carriers of invasive plants which may come into the flora.

The material was collected during the regular field research in the period of 2007-2015. According to pre-planned routes all the territories of Bukhara oasis including natural and artificial landscapes have been covered. During the latest years more than 2000 herbarium specimens from Bukhara oasis have been collected and identified in Central Herbarium of Uzbekistan (TASH). For taxonomic identifications the following sources were used: "Flora of the USSR" (Botschantsev, 1959; Tamamshyan, 1959), "Flora of Uzbekistan" (Bondarenko, 1962; V vedensky, 1962), "Conspectus florae Asiae Mediae" (Tulyaganova, 1993). The main set of herbarium specimens was deposited in the Central Herbarium (TASH). Duplicates are kept in the Herbarium of Bukhara State University. Species nomenclature follows The Plant List (The Plant List, 2013) and additional literature sources dealing with the Bukhara oasis (Guzairov, 1968).

\section{Results}

Erigeron bonariensis Linnaeus, 1753, Sp. Pl. 2: 863.

Described from South America: "America australi". Lectotype (D'Arcy, 1975, in Woodson \& Schery (ed.), Ann. Missouri Bot. Gard. 62: 1021): LINN 994.11.

It is native to South America and naturalized in: Africa, Asia-temperate, Asia-tropical, Australasia, North America, Pacific, South America, North Europe, Middle Europe (Ciortan, Negrean, 2012). Currently it widely expands its secondary distribution areas in North America (Mexico, California), Central America and the Caribbean (Jamaica), Europe, and is registered as a globally invasive species (NGRP, 2015); widely distributed as a weed in tropical and subtropical regions worldwide, exotic. Erigeron bonariensis occurs typically on waste land, around field edges, roadsides, in fallows and in orchards, in both tropical and subtropical regions, and to some extent in temperate zones. The new alien species occurs in inhabited areas, along ditches, abandoned places, in alfalfa fields in the oasis. According to 
our research in the studied areas, the species occurs as 3-16 individuals in $10 \mathrm{~m}^{2}$ area. In Uzbekistan its populations are known from two localities: in Bukhara city and in Karaulbazar district (Fig. 3).

Studied specimens: "Bukhara oasis, Bukhara city, Piridasgir street, along the road, Lucerne field; 210 m. 4007'01.1"N, 64²17'59.9"E. 04 X 2015. H. Esanov, № 510" (TASH; Fig. 1); "Bukhara region. Karaulbazar district, Fergana Street. Alfalfa field, 246 m. 3849'00.0"N, 65¹6'60.0"E. 05 X 2015. H. Esanov, № 514” (TASH).

Note. Erigeron bonariensis is very close to Erigeron canadensis, but they differ from each other in a several morphological characters. Erigeron bonariensis is similar to E. canadensis in its stem, branching, rough hairs, tape-like shape of the leaves, numerous capitula. Dissimilar characters are: in $E$. bonariensis hairs on the stem are very dense, lower leaves saw-toothed, inflorescence wide paniculate, capitula $6 \mathrm{~mm}$ long, $11 \mathrm{~mm}$ wide, inner involucre leaves $4.5 \mathrm{~mm}$ long, $0.7 \mathrm{~mm}$ wide, ligulate flowers $0.3 \mathrm{~mm}$ long, disc flowers five-toothed, pappus 4 $\mathrm{mm}$ long; in E. canadensis hairs on the stem are not dense, lower leaves minutely saw-toothed, inflorescence narrowly paniculate, capitula 4.5-5 $\mathrm{mm}$ long, $8 \mathrm{~mm}$ wide, inner involucre leaves 3.5 $\mathrm{mm}$ long, $0.3 \mathrm{~mm}$ wide, ligulate flowers $0.5-1.0 \mathrm{~mm}$ long, disc flowers four-toothed, pappus $2.5-3.0 \mathrm{~mm}$ long.

Erigeron bonariensis was not found during extensive field surveys in the whole territory of the oasis (including Bukhara city and Karaulbazar district) conducted between 2007 and 2013. It is very likely that the plant arrived in the last three years but the means of its transportation to the area remains unknown. This species is found throughout the tropics and subtropics as a pioneer plant. Erigeron bonariensis according to the current literature (Botschantsev, 1959; Bondarenko, 1962; Tulyaganova, 1993) has never been reported from Central Asia. In the study area it was found with a few populations. For the first time this species has been discovered along roadsides, in plantations and abandoned areas.

Symphyotrichum graminifolium (Spreng.) G. L. Nesom, 1995, Phytologia 77: 283. - Conyza graminifolia Spreng. 1826, Syst. Veg. 3: 515. Conyzanthus graminifolius (Spreng.) Tamamsch. 1959, Fl. URSS 25: 186.

Described from Uruguay: "Monte Video. Sello". Type: "Monte Video. Sello 567" (P 00834826).
Native to the South America. In the secondary areas (South America (Argentina), North Africa and Arabian Peninsula) plants are found in inhabited places, in gardens, along ditches and roads, on fields and abandoned lands, in flowerbeds. In Uzbekistan the species has been spread all over the territory of Bukhara oasis. Initially this plant was collected from Peshku district of the oasis and was found in all territory of the oasis. Mostly observed in damp places (Fig. 2a). It was found in 10-15 individuals in $10 \mathrm{~m}^{2}$.

Studied specimens: "Bukhara oasis, Peshku district, alongside the irrigation ditch, $214 \mathrm{~m}$. 40.116'N, 64.3'E. 7 X 2007. H. Esanov. № 150" (TASH); "Bukhara oasis, Bukhara city, Prospects Navoi, alongside the irrigation ditch, croplands, 224 m. 40 ${ }^{\circ} 15^{\prime} 00.1^{\prime \prime} \mathrm{N}, 64^{\circ} 42^{\prime} 00.0^{\prime \prime} \mathrm{E} .14$ IX 2015. H. Esanov. № 511” (TASH; Fig. 2b).

Note. Genus Symphyotrichum Nees is native to North America (Brouillet et al., 2006). Symphyotrichum graminifolium has been reported as an alien plant from several European countries (Korniyenko, Mosyakin, 2006; Mayorov et al., 2012). In the territory of Central Asia it has been previously found only in the suburbs of Khojand city in Tajikistan (Tulyaganova, 1993). Our record is new to Uzbekistan.

During the years of 2007-2015 the distribution area and populations of $S$. graminifolium in Bukhara were extended. The expansion of the species in the oasis is connected to the habitat conditions (damp places, plantations, irrigated territories, biotic and anthropogenic factors) and as well as to easy and rapid dispersal of its seeds.

Based on the collected data a map on the distribution of the two species on the territory of Uzbekistan has been generated (Fig. 3).

\section{Discussion}

The paper reports the presence and naturalization of Erigeron bonariensis and Symphyotrichum graminifolium as alien plants in Uzbekistan, Bukhara oasis.

Of these alien species, Symphyotrichum graminifolium has a clear tendency to spread further, and may become a new invasive species in Uzbekistan. Further dedicated specialized studies, such as assessment of the impact by using standard scoring systems (Nentwig et al., 2016; Russell, Blackburn, 2017), are needed to monitor the activity of these species in order to reduce their negative impact on the country's nature and agriculture. 


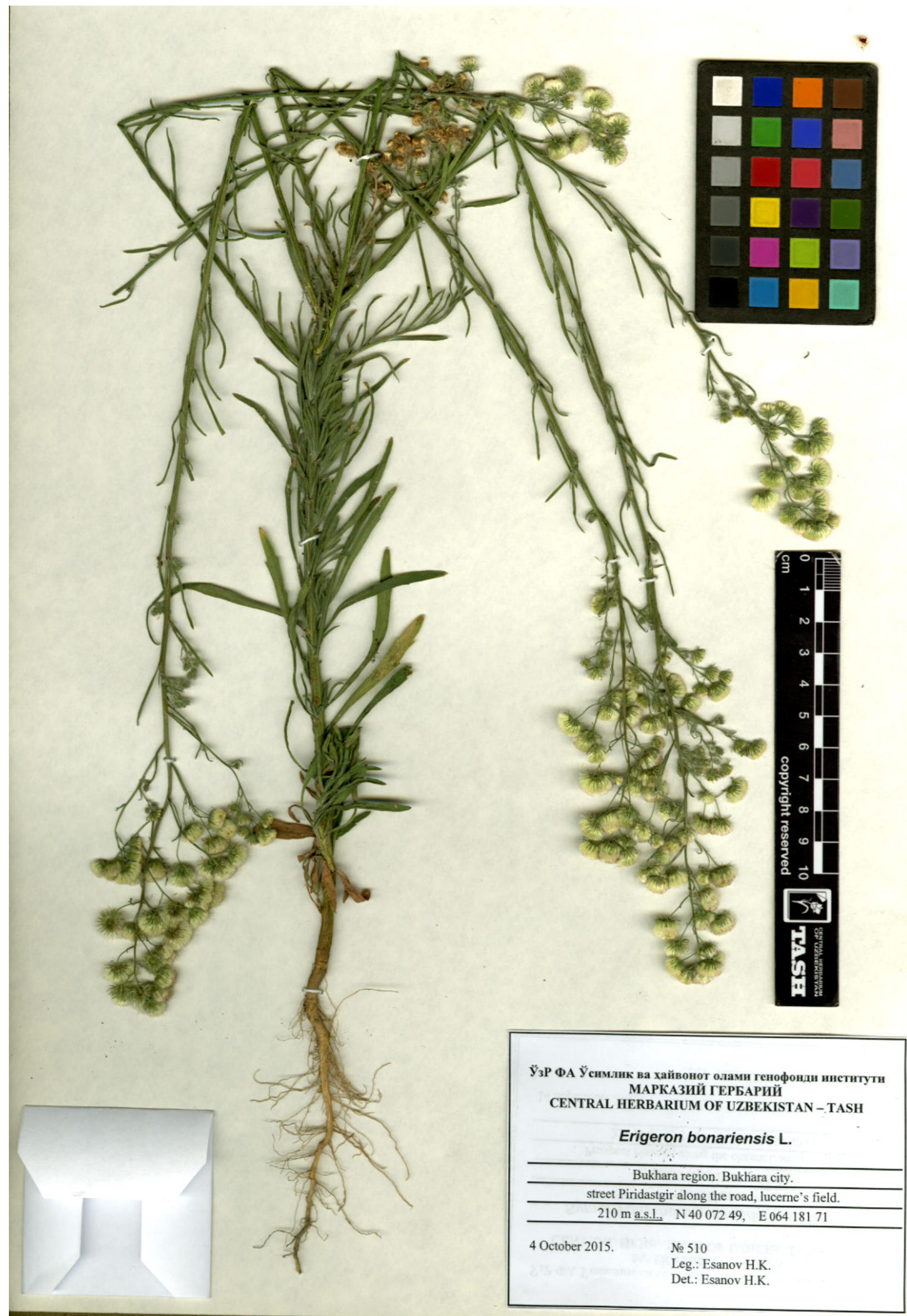

Fig. 1. Herbarium specimen of Erigeron bonariensis from Bukhara city (TASH). 

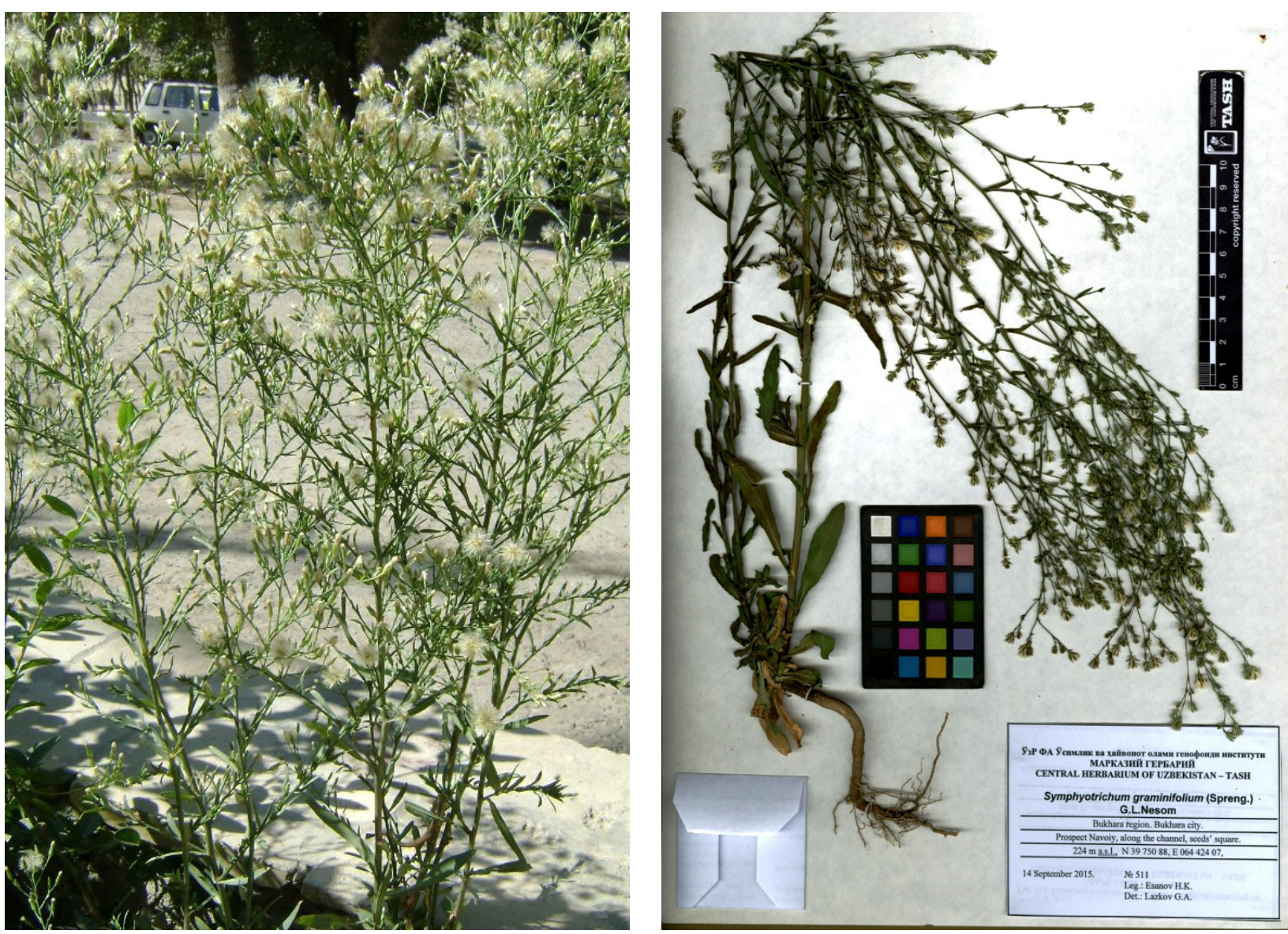

Fig. 2. Habitus of Symphyotrichum graminifolium: a - Bukhara city, Navoi avenue (Photo by Esanov); b - herbarium specimen (TASH).

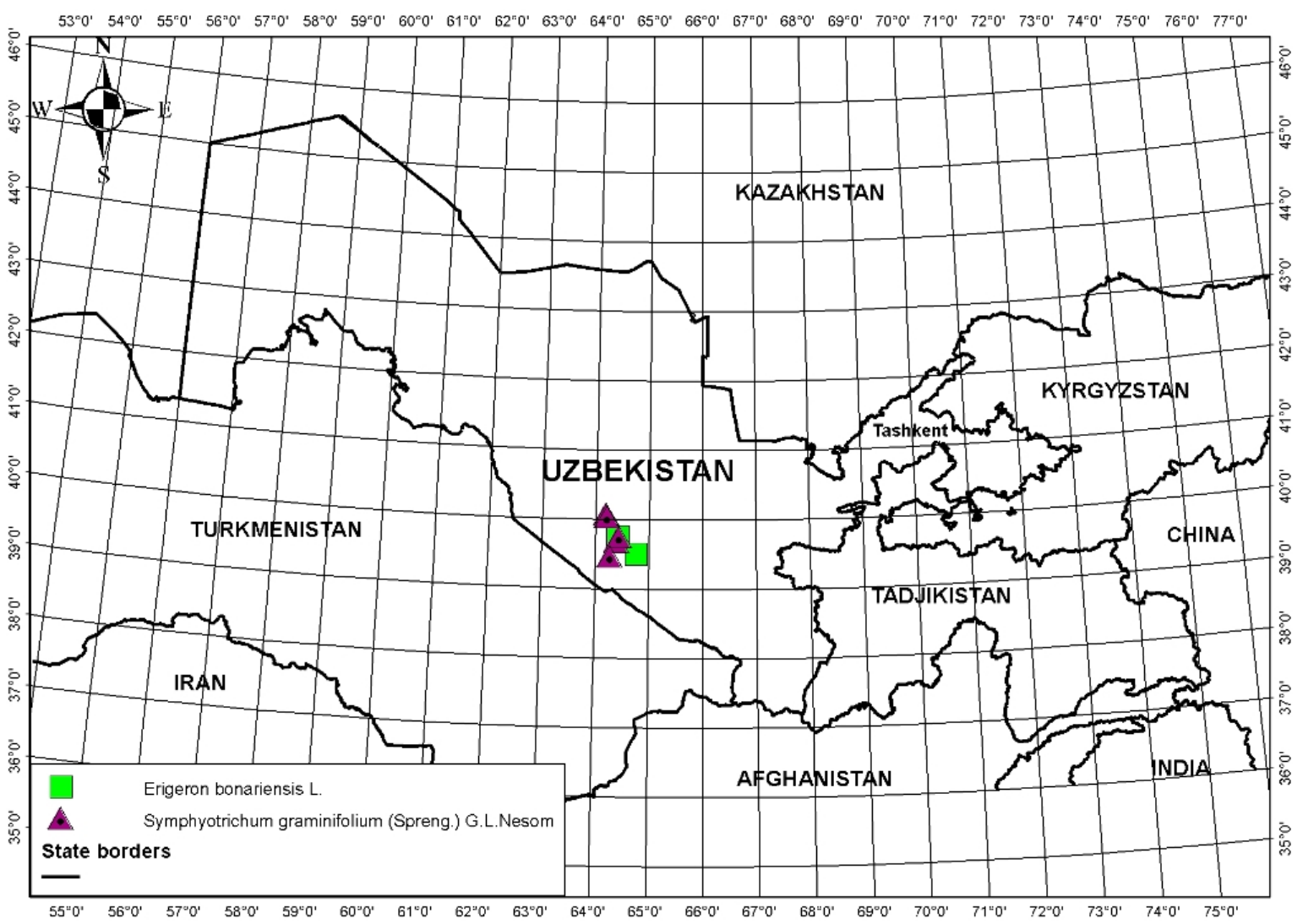

Fig. 3. Distribution map of Symphyotrichum graminifolium and Erigeron bonariensis in Uzbekistan. 
Since new alien species may arrive and spread in Uzbekistan in the future, we hope that this publication will increase awareness of this process and encourage further studies of the alien flora.

\section{Acknowledgements}

The authors express his gratitude to Prof.
K. Sh. Tojibaev and Prof. G. A. Lazkov for their useful advice on preparing the manuscript and identifying the plant species. Also authors gratefully acknowledge to Dr. A. N. Sennikov and Dr. D. V. Geltman for their useful comments; they made many valuable suggestions that greatly improved this article.

\section{REFERENCES / ЛИTEPATУPA}

Bondarenko O. N. 1962. Erigeron L. In: Flora Uzbekistana [Flora of Uzbekistan]. Vol. 6. Academy of Science of Uzbekistan, Tashkent, 47-65 pp. [In Russian]. (Бондаренко О. H. Erigeron L. - Мелколепестник // Флора Узбекистана. Т. 6. Ташкент: Изд-во АН УзССР, 1962. С. 47-65).

Botschantsev V. P. 1959. Erigeron L. In: Flora USSR [Flora of the USSR]. Vol. 25. Publishers of Academy of Sciences of USSR, Moscow \& Leningrad, 191-288 pp. [In Russian]. (Бочанцев И. П. Erigeron L. - Мелколепестник // Флора СССР. Т. 25. М.-Л.: Изд-во АН СССР, 1959. С. 191-288).

Brouillet L., Semple J. C., Allen G. A., Chambers K. L., Sundberg S. D. 2006. Astereae, Senecioneae. In: Flora of North America Editorial Committee. Flora of North America. Vol. 20. Oxford University Press, Oxford, 465-539 pp.

Chen Y. L., Brouillet L. 2011. Symphyotrichum Nees. In: Flora of China (Asteraceae). Vol. 20-21. Science Press (Beijing) and Missouri Botanical Garden Press (St. Louis), 651-652 pp. URL: http://flora.huh.harvard.edu/china/mss/ volume20/Flora of China Volume 2021 Astereae.pdf

Ciortan I., Negrean G. 2012. Conyza bonariensis, a new plant with invasive character in Romanian flora. Annales Univ. Craiova 17: 743-748. URL: http://www.anucraiova.3x.ro/cont/2012-2/126_NegreanG_2.pdf

Esanov H. K., Aslonova K. A. 2015. The distribution of Asteraceae Dumort family species in the Bukhara region. In: The impact of the ecological disaster in the Aral Sea region on nature. Republican Scientific-Practical Conference, Bukhara, 167-169 pp. [In Uzbek]. (Эсанов Х. К., Аслонова К. А. Бухоро вохасида Asteraceae Dumort. оиласи турларининг тарқалиши // Орол денгизи минтақасидаги экологик офатнинг табиатга таъсири. Бухоро: Республика Илмий-Амалий конференцияси, 2015. 167-169 б.).

Guzairov K. 1968. Undesirable plants of uncultivated and field crops of Bukhara. Harmful and useful wild plants of the Bukhara oasis. FAN, Tashkent, $216 \mathrm{pp}$.

Korniyenko O. M., Mosyakin S. L. 2006. Nomenclature of North American asters cultivated and escaped in Ukraine, from the viewpoint of generic delimitation in tribe Astereae (Asteraceae). National Academy of Sciences of Ukraine. Ukrainian Botanical Journal 63(2): 159-165 [In Ukrainian]. (Корніснко О. М., Мосякін С. Л. Номенклатура культивованих та здичавілих в Україні північноамериканських “айстр” з точки зору делімітації родів у трибі Astereae (Asteraceae) // Укр. ботан. журн., 2006. Т. 63, № 2. С. 159-165). URL: http://www.botany. kiev.ua/content_ubj_06.htm

Mayorov S. R., Bochkin V. D., Nasimovich Y. A., Scherbakov A. V. 2012. Alien plants in the flora of Moscow and Moscow region. KMK, Moscow, 412 pp. [In Russian]. (Майоров С. Р., Бочкин В. Д., Насимович Ю. А., Щербаков A. B. 2012. Чужеродные растения во флоре Москвы и Московской области. М.: КМК, 2012. 412 с.).

Nazarov I. K., Allayorov I. S. 1994. Bukhoro Geografiyasi [Geography of Bukhara]. FAN, Bukhara, 66 pp. [In Uzbek]. (Назаров И. К., Шербаков А. Б. Бухоро Географияси. Бухоро: Фан, 1994. 66 б.).

Nentwig W., Bacher S., Pyšek P., Vilà M., Kumschick S. 2016. The generic impact scoring system (GISS): a standardized tool to quantify the impacts of alien species. Environmental monitoring and assessment 188(5): 315. URL: https://doi.org/10.1007/s10661-016-5321-4

Russell J. C., Blackburn T. M. 2017. Invasive Alien Species: Denialism, Disagreement, Definitions, and Dialogue. Trends in ecology \& evolution 32(5): 312-314. DOI: 10.1016/j.tree.2017.02.005

Tamamshyan S. G. 1959. Conyzanthus Tamamsch. In: Flora USSR [Flora of the USSR]. Vol. 25. Publishers of Academy of Sciences of USSR, Moscow \& Leningrad, 186 p. [In Russian]. (Тамамиян С. Г. Conyzanthus Tamamsch. - Конизантус // Флора СССР. Т. 25. М.-Л.: Изд-во АН СССР, 1959. С. 186).

The Plant List, Version 1.1. 2013. URL: http://www.theplantlist.org/ (Accessed 08 June 2017).

National Genetic Resources Program (NGRP). 2015. URL: https://www.ars-grin.gov/ (Accessed 28 November 2015).

Tojibaev K. S., Beshko N. Y., Popov V. A., Jang C. G., Chang K. S. 2016. Botanical geography of Uzbekistan. Korea National Arboretum of the Korea Forest Service, $350 \mathrm{pp}$.

Tulyaganova M. T. 1993. Erigeron L. (Conyza Less.). In: Opredelitel rasteniy Sredney Azii [Conspectus florae Asiae Mediae]. Vol. 10. FAN, Tashkent, 494-500, 513-514 pp. [In Russian]. (Туляганова M. T. Erigeron L. (Сопуzа Less.) - Род Мелколепестник (Кониза) // Определитель растений Средней Азии. Т. 10. Ташкент: ФАН, 1993. С. 494-500, 513-514). 